\title{
Refractivity of Marisa cornuarietis and Other Aquatic Snails in Puerto Rico to Infection with Schistosoma mansoni and Fasciola hepatica ${ }^{1}$
}

\author{
Michael G. Uhrin, Pedro Bendezú, and William R. Jobin ${ }^{2}$
}

\begin{abstract}
Biological control methods for schistosomiasis in man and fascioliasis in cattle include the use of Marisa cornuarietis, a predatory snail. To insure that this snail does not transmit the trematode parasites, laboratory exposures were made under favorable conditions. It was found that Marisa cornuarietis, as well as other potential biological control snails, did not transmit either of the two parasites.
\end{abstract}

\section{INTRODUCTION}

Bilharzia in man and fascioliasis in cattle are spread in Puerto Rico by the snails Biomphalaria glabrata and Lymnaea columella, respectively. In attempts to control these two helminthic diseases, the ampullarid snail Marisa cornuarietis was introduced into waterbodies containing the other snails ${ }^{3}$. Marisa cornuarietis is a useful agent for control of $B$. glabrata, and perhaps $L$. columella, because of the former's appetite for vegetation and snail eggs present on that vegetation. Two other snails, Tarebia granifera and Pomacea australis, may also be useful for biological control of $B$. glabrata since the accidental introduction of these snails has apparently been followed by reduction in numbers of $B$. glabrata. However, it is necessary to study the possible harmful effects of these introducted snails. It may be possible that these control snails are slightly susceptible to Schistosoma mansoni or Fasciola hepatica, suggested by an unconfirmed report from New Zealand that $M$. cornuarietis imported from Trinidad were shedding cercariae. This observation could have several explanations, including the possibility that $S$. mansoni or $F$. hepatica was involved, or perhaps a mistaken identification of some other microorganism. Thus, this study was undertaken to determine whether $M$. cornuarietis could transmit these parasites, de-

' Contribution of Center for Energy and Environment Research, University of Puerto Rico. The authors are grateful to Dr. F. F. Ferguson and Miss Marta Caballero for their advice and assistance on this study.

${ }^{2}$ Oak Ridge Undergraduate Fellow, summer of 1975; Parasitologist, Agricultural Experiment Station, Mayagüez Campus, University of Puerto Rico, Río Piedras, P.R.; and Head of Human Ecology Division, Center for Energy and Environment Research, San Juan, P.R.

${ }^{3}$ Ferguson, F. F., Oliver-González, J., and Palmer, J. R., Potential for biological control of Australorbis glabratus the intermediate host of Puerto Rican schistosomiasis, Am. J. Trop. Med. Hyg. 7(5): 491-3, 1958. 
spite general indications to the contrary ${ }^{4}$. T. granifera and $P$. australis were also evaluated because of their potential as biological control agents, although the Brazilian strain of $P$. australis was previously reported to be refractive to $F$. hepatica ${ }^{5}$.

\section{MATERIALS AND METHODS}

The research included two phases: the examination of field-collected snails for natural infections of the parasites, and the laboratory exposure of snails to infection. The first phase included collection of $P$. australis and $M$. cornuarietis from Cañaboncito River in Caguas, and $T$. granifera from a stream in Caguas, from the Mameyes River near Palmer, and from several small streams on the lower north slope of El Yunque mountain. The snails were taken to the laboratory and exposed to light for 2 to $3 \mathrm{~h}$ every morning and examined in the afternoon under a dissecting microscope for cercariae. This examination was repeated on 5 consecutive days for all collected snails.

Additional snails were collected for the second phase of exposure to the parasites. B. glabrata and $L$. columella were used to verify the infectiveness of the miracidia of $S$. mansoni and $F$. hepatica. Prior to miracidial exposure, the snails were housed in identical aerated aquaria, half-filled with nonchlorinated water.

Three separate experiments were performed using $S$. mansoni miracidia. The first two experiments utilized the laboratory strain of $B$. glabrata from the Puerto Rico Nuclear Center, while the third used $B$. glabrata collected in the field near the Rum Pilot Plant of the Agricultural Experiment Station in Río Piedras, to determine whether the infectivity of the laboratory strain was different from that of the field snails. Miracidia were obtained by mincing two to five livers of white mice in a blender with $600 \mathrm{ml}$ of nonchlorinated water for $1 \mathrm{~min}$.

In each experiment 26 snails of each of the four species were exposed to $S$. mansoni. For each species 13 pairs of snails were each placed in a $300-\mathrm{ml}$ glass with $200 \mathrm{ml}$ of nonchlorinated water $1 \mathrm{~h}$ prior to miracidial exposure. Ten miracidia were counted onto a watchglass which was then submerged with the two snails for 3 to $5 \mathrm{~s}$ and removed. Snails were fed prepared food $1 \mathrm{~h}$ after exposure; the day after exposure each snail was measured to the nearest $0.5 \mathrm{~mm}$ and placed in an aquarium of the same specifications as before. One aquarium was used to house the snails from each of the three series of exposures. These snails were examined

4 Richards, C. S., Infectivity of Schistosoma mansoni for Puerto Rican mollusks including a new potential intermediate host, Am. J. Trop. Med. Hyg. 12(1): 26-33, 1963.

${ }^{5}$ De León, D., On the experimental infection of Pomacea australis, refractive for Fasciola hepatica but receptive to Angiostrongylus cantonensis, J. Agr. Univ. P.R. 54(2): 411-12, 1970. 


\section{Journal of Agriculture of University of Puerto Rico}

40 days post exposure for cercarial shedding. Snails were then examined for schistosome sporocysts by crushing them between glass slides since it was thought that a nonspecific snail might retard maturation of the sporocyst.

The experiments with Fasciola hepatica were similar to those with $S$. mansoni except that $L$. columella snails were used to test the infectivity of the parasite, and only $M$. cornuarietis was tested for susceptibility. Ten $M$. cornuarietis were placed in each of six aquaria and exposed to 1000 miracidia of $F$. hepatica, a ratio of 100 miracidia per snail. The miracidia were hatched from eggs taken from infected gall bladders of four cows from the Caguas slaughterhouse. In a separate aquarium 50 $L$. columella were exposed to 1000 miracidia from the same batch as those used for the $M$. cornuarietis, a ratio of 20 miracidia per snail.

The water in the aquaria was examined daily for metacercariae and 10 Marisa cornuarietis were crushed and examined microscopically 30 and 45 days after exposure. Finally, all remaining $M$. cornuarietis were crushed and examined at 60 days. The $L$. columella were all crushed and examined 30 days after exposure.

\section{RESULTS AND DISCUSSION}

None of the $76 \mathrm{M}$. cornuarietis, $76 \mathrm{P}$. australis, and 1,142 T. granifera adult snails collected from natural habitats were shedding cercariae of any kind. The results of the laboratory exposure of these snails to $S$. mansoni also were negative (table 1 ). The $B$. glabrata exposed to these miracidia had an infection rate of about $50 \%$ with no significant difference between replicates.

Of the $60 \mathrm{M}$. cornuarietis exposed to Fasciola hepatica, none were found infected, while $72 \%$ of the $50 \mathrm{~L}$. columella were infected. Thus, the unconfirmed incident of cercariae from $M$. cornuarietis was not due to either $S$. mansoni or $F$. hepatica and was probably a misidentification.

The minor possibility that these snails might have somehow become susceptible to dangerous parasites found in Puerto Rico can be discarded. This was taken seriously, however, due to the sketchy report

TABLE 1. - Numbers of snails shedding cercariae or showing sporocysts of Schistosoma mansoni

\begin{tabular}{|c|c|c|c|c|c|c|c|c|c|c|}
\hline \multirow[b]{2}{*}{ Species } & \multicolumn{3}{|c|}{ Experiment 1} & \multicolumn{3}{|c|}{ Experiment 2} & \multicolumn{3}{|c|}{ Experiment 3} & \multirow{2}{*}{$\begin{array}{l}\text { Range of } \\
\text { diameters }\end{array}$} \\
\hline & $\begin{array}{l}\text { Posi- } \\
\text { tive }\end{array}$ & $\begin{array}{l}\text { Nega- } \\
\text { tive }\end{array}$ & Dead & $\begin{array}{l}\text { Posi- } \\
\text { tive }\end{array}$ & $\begin{array}{l}\text { Nega- } \\
\text { tive }\end{array}$ & Dead & $\begin{array}{l}\text { Posi- } \\
\text { tive }\end{array}$ & $\begin{array}{l}\text { Nega- } \\
\text { tive }\end{array}$ & Dead & \\
\hline & & & & & & & & & & $\mathrm{mm}$ \\
\hline B. glabrata & 14 & 6 & 6 & 9 & 12 & 5 & 12 & 9 & 5 & 8 to 24 \\
\hline M. cornuarietis & 0 & 26 & 0 & 0 & 24 & 2 & 0 & 26 & 0 & 16 to 50 \\
\hline$P$. australis & 0 & 23 & 3 & 0 & 22 & 4 & 0 & 25 & 1 & 10 to 36 \\
\hline$T$. granifera & 0 & 23 & 3 & 0 & 25 & 1 & 0 & 24 & 2 & 5 to $20^{1}$ \\
\hline
\end{tabular}

${ }^{1}$ Length. 
from New Zealand and because of a statement by Richards that "repeated miracidial attacks or prior infection with other trematodes may result in some change in host-parasite relationship such that development can proceed to the shedding of cercariae" (2).

Since this study clarifies the lack of risk involved in using $M$. cornuarietis and the other snails for biological control in Puerto Rico, research in this area should be encouraged.

\section{RESUMEN}

El caracol predatorio Marisa cornuarietis constituye de por sí uno de los métodos para el control biológico de la bilharzia y la Fasciola. Para determinar si este caracol puede ser huésped intermediario de los parásitos, en el laboratorio se expuso a infección bajo condiciones favorables. Sin embargo, ni Marisa cornuarietis ni los otros caracoles de uso potencial trasmitieron los parásitos. 